\title{
PENGEMBANGAN GAME EDUKASI PEMBIAKAN LELE MENGGUNAKAN MECHANICS DYNAMICS AESTHETICS (MDA) FRAMEWORK
}

\author{
Ali Sofyan Kholimi ${ }^{1}$, Sugeng Prasetiyono ${ }^{2}$, Lailatul Husniah ${ }^{3}$ \\ 1,2,3 Informatika, Universitas Muhammadiyah Malang \\ Malang, Indonesia
}

e-mail: kholimi@umm.ac.id ${ }^{1}$, sugeng.prasetiyono@gmail.com², husniah@umm.ac.id ${ }^{3}$

\begin{abstract}
Abstrak
Indonesia merupakan negara beriklim tropis dengan sebagian besar wilayahnya merupakan perairan. Potensi alam ini memberikan kesempatan besar pada Indonesia untuk mensuplai ikan, baik ikan air laut maupun ikan air tawar, ke dalam pasar internasional. Kenaikan produksi budidaya ikan dalam kolam air tawar cukup pesat yaitu berkisar 11 persen setiap tahun dan salah satu ikan air tawar yang populer untuk dibudidayakan adalah Lele. Naiknya tren perikanan budidaya di dunia juga mengakibatkan naiknya permintaan pelatihan budidaya ikan air tawar beserta mediamedia pelatihannya. Salah satu media pelatihan yang banyak digunakan di dalam pelatihan adalah buku dan video. Namun, Buku dan video memiliki kekurangan dalam hal interaksi aktif antara pengguna kedua media tersebut dan medianya. Game merupakan salah satu alternatif media pembelajaran selain buku dan video yang memiliki kelebihan dalam hal interaksi dengan penggunanya dibandingkan dengan buku dan video. Penelitian ini mencoba untuk mengimplementasikan pembelajaran budidaya ikan Lele dalam sebuah game. Budidaya ikan Lele dipilih karena berdasarkan laporan Kementrian Kelautan dan Perikanan (KKP) memiliki pangsa pasar terbesar untuk pasar ikan air tawar. Metode yang digunakan untuk mengimplementasikan game manajemen ikan Lele ini adalah Mechanics-Dynamics-Aesthethics (MDA) Framework. Pengujian dengan menggunakan GameFlow Test menunjukkan rata-rata skor nilai sebesar $3.36(67.2 \%)$ yang berarti bahwa hasil implementasi game ini bisa diterima dengan baik oleh pemain.
\end{abstract}

Kata kunci: MDA Framework, GameFlow Test, Game Edukasi, Budidaya Lele

\begin{abstract}
Indonesia is a country with a tropical climate where most of its territory is water. This natural potential provides an excellent opportunity for Indonesia to supply fish, both seawater and freshwater fish, to the international market. The increase in fish culture production in freshwater ponds is relatively rapid, around 11 percent every year, and one of the popular freshwater fish for cultivation is catfish. The increasing trend in aquaculture has also increased the demand for freshwater aquaculture training and training media. One of the training media that more used in training is books and videos. However, Books and videos lack the active interaction between users of both media and their media. Games are an alternative learning media besides books and videos, which have advantages in terms of interaction with users compared to books and videos. This study tries to implement catfish farming learning in a game. Catfish farming chooses because it has the largest market share for the freshwater fish market based on a report from the Ministry of Marine Affairs and Fisheries (KKP). The method used to implement this catfish management game is the Mechanics-Dynamics-Aesthetics (MDA) Framework. Testing using the GameFlow Test shows an average score of 3.36 (67.2\%), which means that players can well receive the results of this game's implementation..
\end{abstract}

Keywords : MDA Framework, Game Flow Test, Educational Games, Catfish Farming 


\section{PENDAHULUAN}

Penelitian dalam game untuk edukasi memiliki 4 (empat) perspektif yang terdiri dari (1) Teori, (2) Kognitif dan psikologi, (3) Instruksional, (4) Pengajaran dan Pembelajaran [1]. Game edukasi memiliki berbagai subjek yang digunakan dalam pembelajaran, termasuk di antaranya Sejarah, Sains, Bahasa, Desain, Matematika, Kesehatan, dan sebagainya. [1], [2]

Indonesia merupakan negara beriklim tropis dengan sebagian besar wilayahnya merupakan perairan. Potensi alam ini memberikan kesempatan besar pada Indonesia untuk mensuplai ikan, baik ikan air laut maupun ikan air tawar, ke dalam pasar internasional.

Selain potensi alam, potensi pasar ikan di Indonesia juga besar. Berdasarkan laporan Kementrian Kelautan dan Perikanan (KKP), pertumbuhan rata-rata konsumsi ikan di Indonesia sebesar 5,04 persen per tahun, jauh diatas Malaysia yang hanya 1,26 persen per tahun. Tidak hanya potensi pasar ikan di Indonesia, pasar ikan dunia juga memiliki potensi yang besar. Sebagaimana laporan Badan Pangan Dunia (FAO), pada tahun 2021 konsumsi ikan perkapita penduduk dunia akan mencapai 19,6 kg per tahun. [3]

Walaupun volume konsumsi naik, volume produksi ikan tangkapan akan berkurang. Hal ini terjadi akibat dari overfishing, sehingga ikan di laut semakin sulit didapatkan. Hal tersebut dapat diatasi salah satunya dengan peningkatan produksi budidaya ikan air tawar yang diperlukan sebagai subtitusi ikan laut. Hal ini terlihat dari kenaikan produksi budidaya ikan dalam kolam air tawar yang cukup pesat yaitu berkisar 11 persen setiap tahun [3]. Salah satu ikan air tawar yang populer untuk dibudidayakan adalah ikan Lele [3], [4].

Naiknya tren perikanan budidaya di dunia juga mengakibatkan naiknya permintaan pelatihan budidaya ikan air tawar beserta media-media pelatihannya [5]. Salah satu media pelatihan yang banyak digunakan di dalam pelatihan adalah buku dan video. Kelebihan dari buku adalah kelengkapan materinya, sedang video memiliki kelebihan dalam menyampaikan materi secara visual. Namun, ada satu kelemahan yang sama-sama dimiliki oleh media buku dan video. Buku dan video memiliki kekurangan dalam hal interaksi aktif antara pengguna kedua media tersebut dan medianya.

Game merupakan salah satu alternatif media pembelajaran selain buku dan video. Game memiliki kelebihan dalam hal interaksi dengan penggunanya dibandingkan dengan buku dan video. Beberapa game telah dibuat sebagai media belajar pada topik tertentu, namun belum ditemukan yang berkaitan dengan pembelajaran budidaya ikan. [6]-[12] Berdasarkan pencarian di Google Playstore, game yang memberikan informasi mengenai budidaya ikan juga sangat sulit untuk di temukan. [13]

Budidaya Ikan merupakan kegiatan untuk memelihara, membesarkan, dan/atau membiakkan ikan serta memanen hasilnya dalam lingkungan yang terkontrol, termasuk kegiatan yang menggunakan kapal untuk memuat, mengangkut, menyimpan, mendinginkan, menangani, mengolah dan/atau mengawetkannya [14]. Dalam kegiatan budidaya ikan di Indonesia seringkali beberapa kelompok seperti budidaya Ikan Hias dan budidaya Ikan untuk Konsumsi. Untuk budidaya ikan konsumsi ini terbagi atas 3 proses yaitu 1) Proses persiapan bibit, 2) Proses Pembesaran, dan 3) Proses Penjualan. [15]

Proses persiapan bibit dimulai dari pemilihan indukan ikan, proses pembuahan, dan proses pemeliharaan telur sampai menjadi bibit dengan ukuran yang cukup untuk proses pembesaran. Proses Pembesaran adalah proses dimana bibit hasil pembibitan akan mulai diberikan perawatan mulai dari pemberian pakan dengan protein tinggi, pengecekan kondisi kolam agar ikan tetap sehat, dan pengukuran ikan pada rentang waktu tertentu untuk melihat apakah ikan sudah siap untuk di jual. Proses Penjualan dimulai dari penyortiran ukuran ikan untuk 
menentukan harga dan Penjualan pada penadah agar bisa di distribusikan.

Penelitian ini, mengembangkan game sebagai sarana edukasi mengenai budidaya ikan terutama ikan air tawar, dalam hal ini dibatasi pada budidaya ikan Lele.

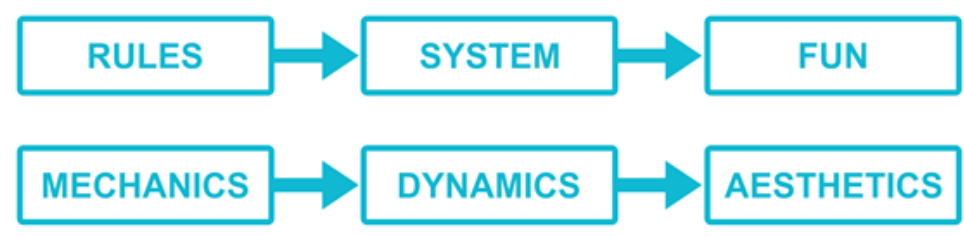

Gambar 1. Metode MDA Framework

\section{METODE}

Metode yang digunakan dalam penelitian ini adalah metode pengembangan game dengan menggunakan metode Mechanics-Dynamics-Aesthethics (MDA) Framework. MDA Framework dipilih karena metode ini memiliki detail yang lebih pada proses perancangan game Seperti pada tahap Pre-Production dan Production jika di metode Game Development Life Cycle (GDLC).

MDA Framework merupakan kerangka kerja yang digunakan dalam menganalisa aspek-aspek yang ada pada sebuah game. Pada framework ini terbagi atas 3 komponen utama yaitu Mechanic, Dynamic, dan Aestethic, sebagaimana ditunjukkan pada Gambar 1.. [9], [16] Seluruh konten pada game budidaya ikan ini dirancang dan diimplementasikan dalam supervisi pakar di bidang perikanan.

\section{Mekanik (Mechanic)}

Pada game ini ada beberapa aturan permainan yang dibagi menjadi 3 (tiga) bagian, yakni mekanik kolam, mekanik toko, dan mekanik tugas.

\section{Mekanik Kolam}

Pada bagian mekanik kolam ini pemain akan melakukan beberapa hal dasar dalam proses budidaya ikan seperti perawatan ikan dan perawatan kolam. Peraturan pada perawatan ikan dirancang agar pemain memperhatikan tingkat lapar dari Ikan dan memberikan obat untuk ikan yang sakit. Peraturan pada perawatan kolam mulai dari mengatur kadar oksigen, kadar $\mathrm{pH}$, dan kebersihan agar kesehatan ikan tetap terjaga. Proses pada mekanik kolam ini secara umum ditunjukkan oleh Gambar 1 dan desain antarmuka ditunjukkan oleh Gambar 2. 


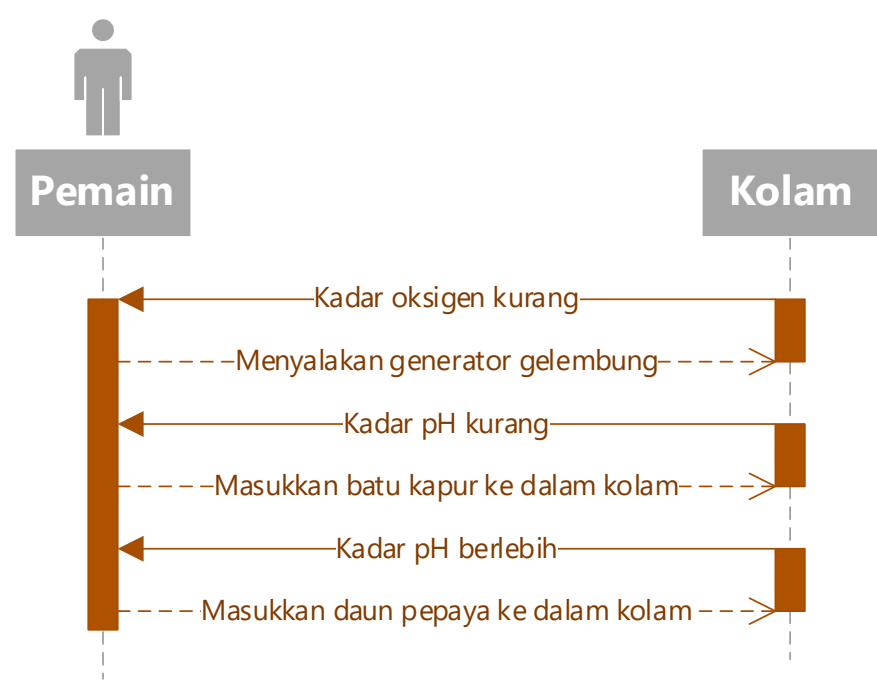

Gambar 2. Disain proses perawatan kolam

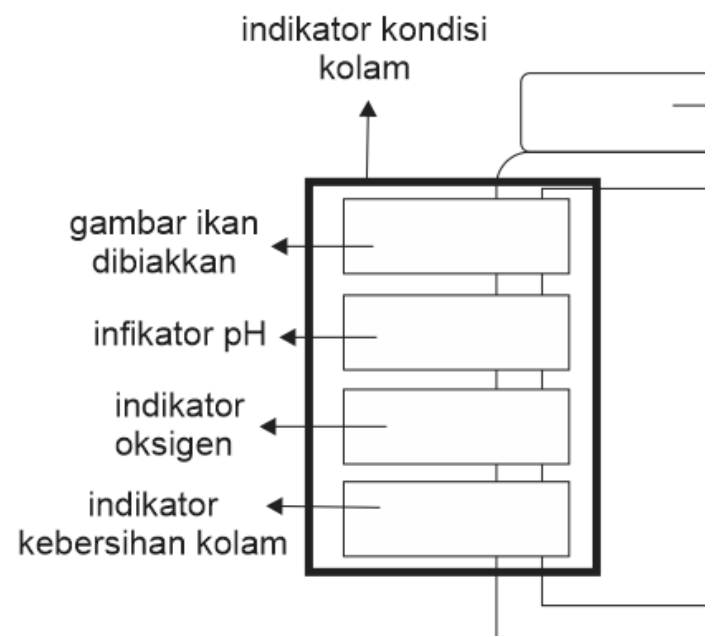

Gambar 3. Disain antarmuka Indikator Kolam

Pemberian makan ikan dilakukan oleh pemain dengan melihat indikator yang tersedia. Apabila indicator tingkat lapar ikan menunjukkan ikan dalam kondisi lapar, pemain harus memilih menu untuk memberi makan tingkat lapar ikan berkurang. Pemberian pakan pada ikan juga harus sesuai untuk ukuran ikan pada saat itu agar pertumbuhan ikan dapat maksimal. Apabila pemain terlambat dalam memberi makan, ikan akan mengalami penurunan kesehatan yang dapat mengakibatkan kematian.

Pemberian Obat untuk ikan dilakukan oleh pemain apabila Indikator Kesehatan menunjukkan bahwa ikan yang ada dalam kolam ada yang terkena penyakit. Jenis obat yang diberikan harus disesuaikan dengan penyakit pada ikan. Jika penyakit belum bisa di sembuhkan dalam waktu tertentu kesehatan ikan juga akan mengalami penurunan.

Pengaturan kadar Oksigen pada kolam dilakukan dengan menekan mesin udara yang ada di tepi kolam untuk meningkatkan kadar oksigen dalam kolam. Proses pengaturan kadar oksigen ini juga memiliki biaya tertentu yang akan mengurangi jumlah uang yang dimiliki oleh pemain.

Pengaturan kadar $\mathrm{pH}$ dalam kolam dilakukan pemain dengan memilih batu kapur untuk menaikkan kadar $\mathrm{pH}$ atau daun 
pepaya untuk menurunkan kadar $\mathrm{pH}$. Pembersihan kolam ikan hanya bisa dilakukan oleh pemain saat kondisi kolam kosong dan akan diisi oleh ikan kembali. Setelah pembersihan kolam dilakukan, kolam siap diisi ikan Kembali. Pembersihan kolam akan mengeluarkan biaya tertentu dan mengurangi variable uang yang dimiliki oleh pemain.

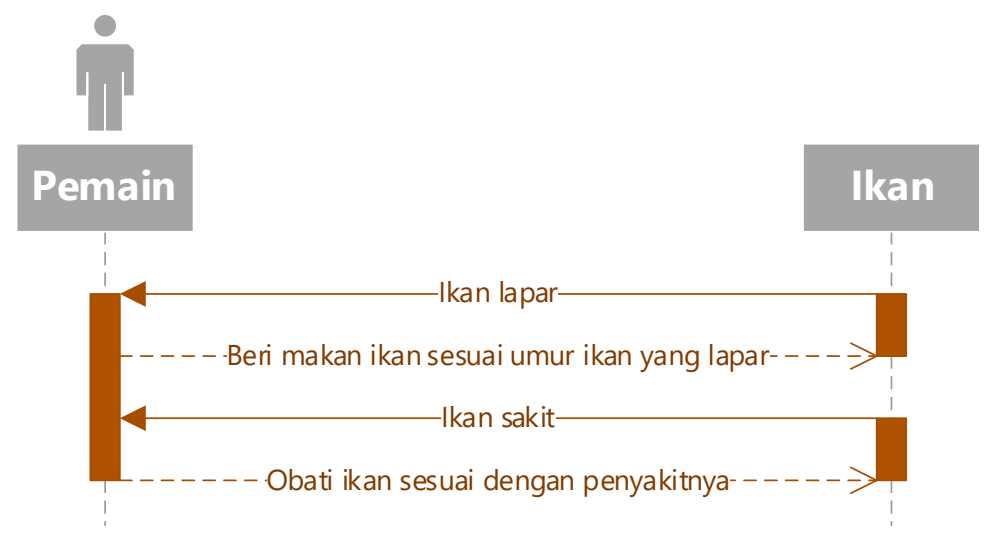

Gambar 4. Disain proses perawatan ikan

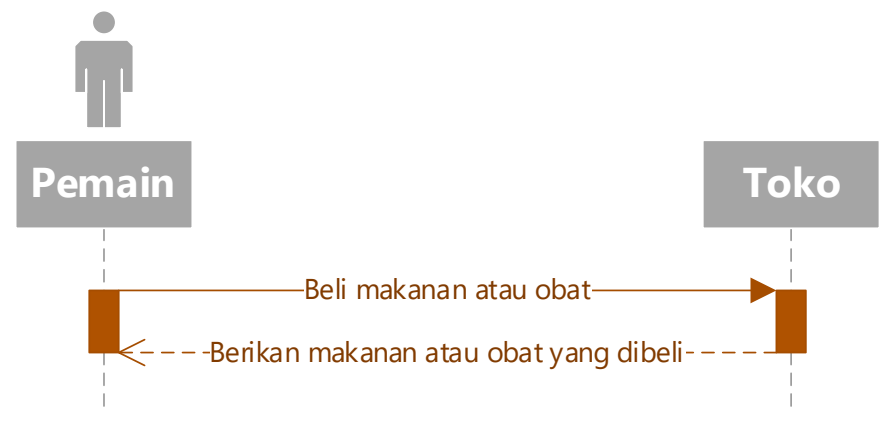

Gambar 5. Disain proses jual beli di toko

\section{Mekanik Toko}

Mekanik toko dirancang untuk menyediakan kebutuhan pemain dalam melakukan perawatan ikan dan perawatan kolam. Rancangan proses pada mekanik toko ini secara umum ditunjukkan oleh Gambar 5.

Mekanik toko dirancang untuk proses pembelian bahan saja seperti pembelian benih atau bibit Ikan, pembelian pakan dan obat, dan pembelian kebutuhan tambahan. Pemain hanya bisa membeli barang dari toko jika syarat tertentu sudah terpenuhi, seperti uang, jumlah maksimum kolam dalam menampung ikan, dan lainnya. Pemain juga dapat menambah kolam apabila kolam ingin memperbanyak budidaya ikan dengan cara membeli kolam baru dan pemain akan mendapatkan notifikasi saat melakukan pembelian kolam baru.

Pembelian benih ikan dilakukan oleh pemain dengan cara memilih terlebih dahulu kolam ikan yang sudah siap digunakan. Pemain dapat menentukan berapa jumlah ikan yang akan diletakan dalam kolam tersebut dengan jumlah maksimal kapasitas daya tampung ikan pada kolam. Disain antarmuka untuk Pembelian Bibit Ikan ditunjukkan oleh Gambar 6.

Pembelian pakan dan obat untuk ikan bisa dilakukan pemain hanya cukup dengan cara menentukan berapa banyak barang yang akan dibeli. Pembelian kebutuhan 
tambahan, seperti pembelian kolam baru untuk menambah kapasitas produksi ikan, tidak tersedia pada toko. Pemain bisa langsung menekan tombol beli di kolam setelah memilih kolam yang belum terbuka. Disain antarmuka untuk Pembelian Obat dan Pakan ditunjukkan oleh Gambar 7.

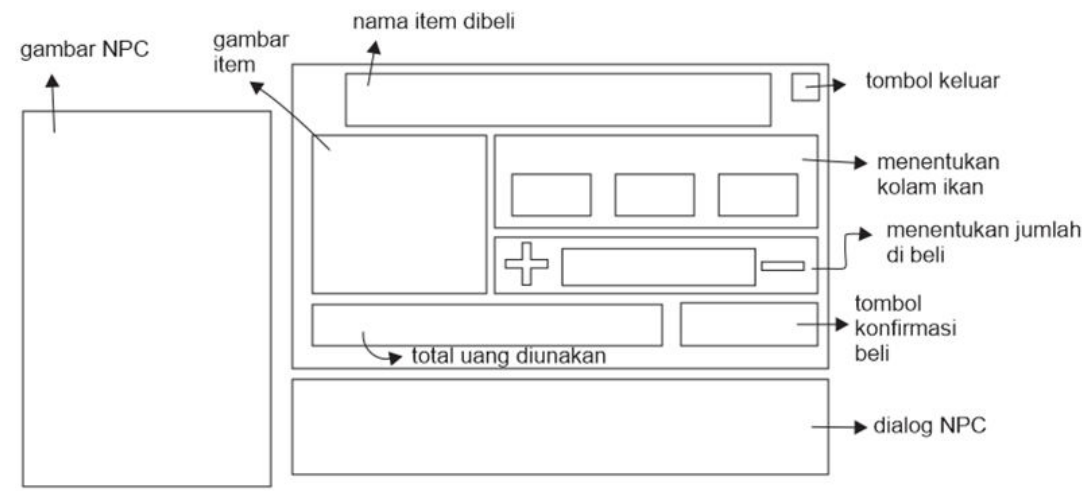

Gambar 6. Disain antarmuka untuk Pembelian Bibit Ikan

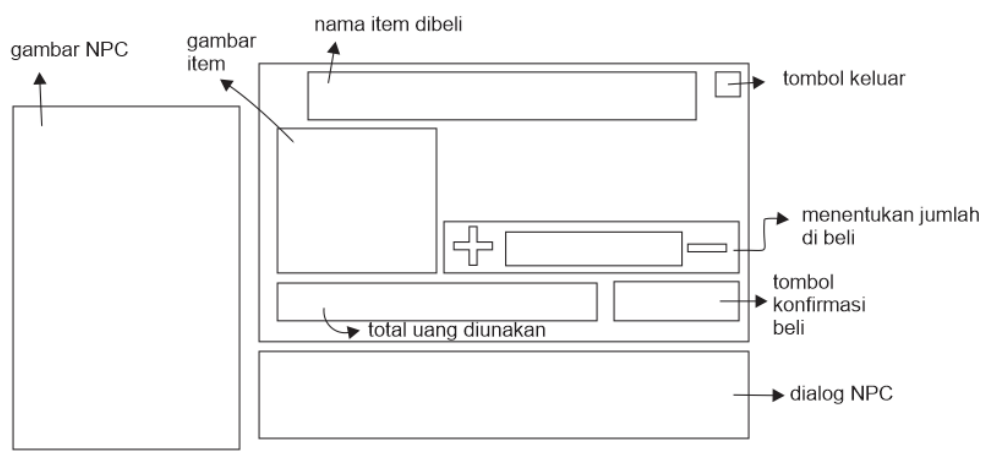

Gambar 7. Disain antarmuka untuk Pembelian Obat dan Pakan

\section{Mekanik Tugas}

Mekanik Tugas sendiri merupakan cara pemain untuk mendapatkan uang yang nantinya akan digunakan untuk membeli kebutuhan dalam melakukan budidaya. Tugas dibagi atas 2 (dua) jenis yaitu Main dan Sub.

Tugas "Main" merupakan tujuan jangka panjang yang digunakan pemain sebagai arahan untuk menyelesaikan game ini. Setiap pemain yang berhasil menyelesaikan tugas akan mendapatkan hadiah berupa tambahan uang dalam jumlah tertentu. Sedangkan dalam Tugas "Sub" digunakan untuk melakukan penjualan ikan yang sudah dibesarkan. Sama halnya dengan Tugas Main, pemain juga akan mendapatkan hadiah tambahan berupa uang namun memiliki nilai yang lebih sedikit dibanding Tugas Main jika berhasil menyelesaikannya. Disain antarmuka untuk Tugas "Main" dan Tugas "Sub" dapat dilihat pada Gambar 8. 


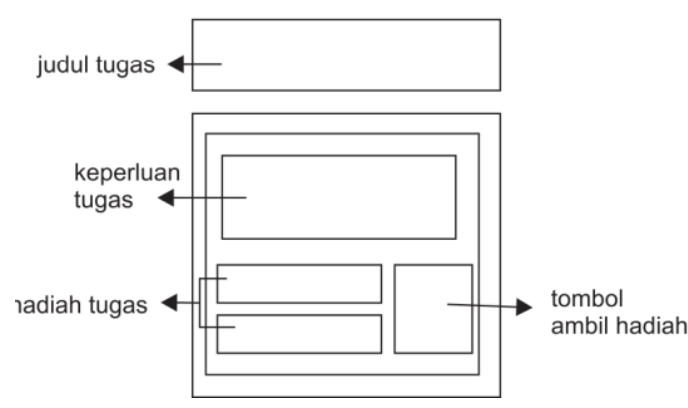

(a)

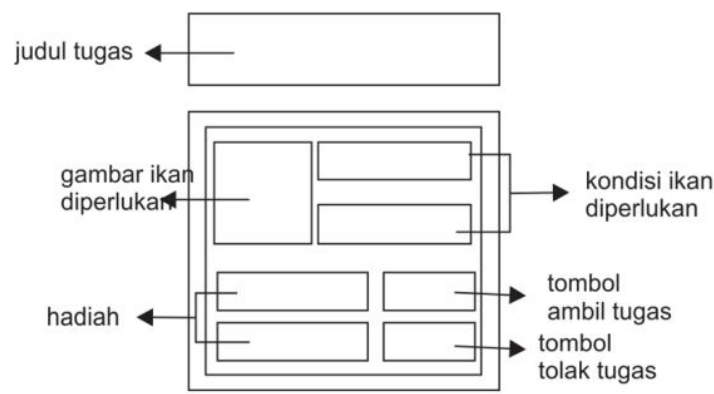

(b)

Gambar 8. Disain antarmuka untuk (a) Tugas "Main" dan (b) Tugas "Sub"

\section{Dynamic}

Dynamic diidentifikasi sebagai interaksi pemain dengan mekanik itu sendiri dan menggambarkan bagaimana sebuah aturan dalam game bertindak, menanggapi masukan pemain dan bekerja sama dengan aturan lain, dalam istilah pemrograman disebut sebagai perilaku "run-time" dari game [9], [16], [17].

Dynamic pada game ini dirancang untuk sistem pada kolam yang akan membantu pemain memperoleh Discovery pada bagian Aesthetic. Pemain dapat mengetahui faktor apa saja yang dapat mempengaruhi proses pembesaran ikan. Dalam kolam akan ditunjukan beberapa faktor seperti kadar oksigen, tingkat $\mathrm{pH}$, dan kebersihan kolam dapat mempengaruhi kesehatan ikan. Faktor-faktor tersebut akan berubah berdasarkan variable-variable tertentu seperti jumlah ikan, ukuran ikan, dan lainnya. Selain itu pemilihan pakan yang diberikan pada ikan juga bisa mempengaruhi perubahan berat ikan setelah waktu tertentu.

Dampak pemberian pakan pada ikan dapat dilihat dari indikator yang telah disediakan pada kolam (Gambar 9). Selain itu, indikator pada toko juga akan membantu dalam sisi Discovery. Misal pada pakan pemain bisa mengetahui garis besar bagaimana pakan yang akan digunakan untuk pembesaran. Pada bagian obat dan lainnya pemain bisa mengetahui penyakit apa saja yang sering menyerang ikan atau kebetuhan apa saja yang sering dibutuhkan dalam proses pembesaran ikan.

Untuk mendapatkan uang pemain diharuskan melakukan perawatan ikan yang sesuai dengan Tugas yang diberikan. Hal ini ditujukan agar pemain tidak merasa kebingungan ikan apa yang harus dibesarkan saat ini. Selain itu syarat yang dipasang pada tugas juga memberikan tantangan pada pemain untuk melakukan perawatan ikan dengan baik.

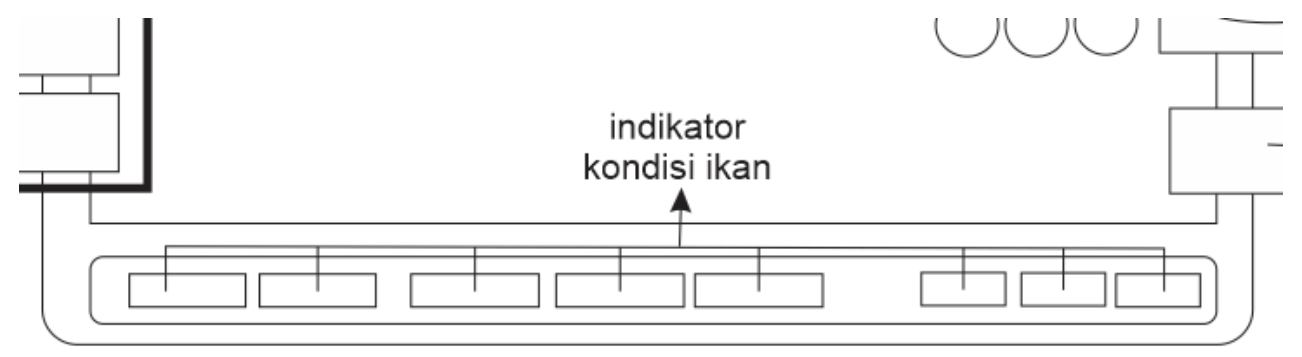

Gambar 9. Disain dan rancangan untuk Indikator Ikan

Aesthetic

Pada bagian Aesthetic MDA

Framework disediakan 8 poin yang akan diperoleh pemain ketika bermain game dimainkan seperti Sensation, Fantasy,
Narrative, Challenge, Fellowship, Expression, dan Submission [16]. Dari 8 poin tersebut ada 2 poin yang digunakan pada Game ini yaitu Challenge dan Discovery. 
Pada bagian challenge pemain harus bermain dengan strategi bagaimana cara menyiapkan ikan dan menyesuaikan dengan apa yang diinginkan oleh pembeli. Pemain juga disajikan Task yang diberikan oleh NPC pada game untuk melihat seberapa baik pemain dapat mengatur budidaya ikan yang dimilikinya.

Pada bagian Discovery, pemain melakukan tindakan perawatan ikan dan kolam. Pada proses perawatan ikan pemain bisa menentukan pakan apa yang diberikan pada ikan yang dirawatnya dan obat apa yang diperlukan jika ikan terkena penyakit tertentu. Pada sisi perawatan kolam pemain dapat mengetahui bagaimana cara mengatur kolam mulai dari jumlah Air pada kolam, kadar Oksigen dan tingkat $\mathrm{pH}$ agar ikan dapat berkembang dengan baik.

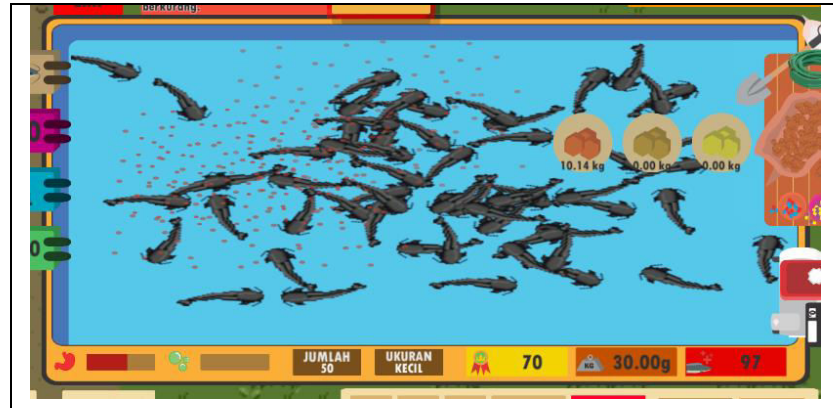

(a)

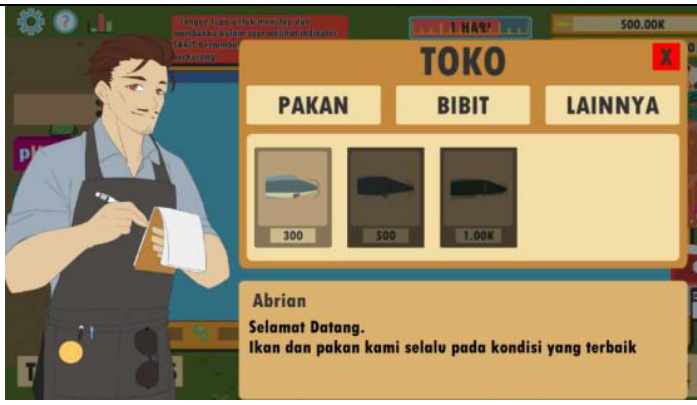

(b)

Gambar 10. Implementasi disain (a) Model Kolam dan (b) Model Toko

\section{HASIL DAN PEMBAHASAN}

Implementasi model kolam dan toko sesuai dengan disain dan rancangan dapat dilihat pada Gambar 8. Gambar 9 (a) adalah implementasi disain dan rancangan saat pemain mempersiapkan kolam dengan menampilkan informasi Indikator Kolam yang meliputi gambar ikan, indicator derajat keasaman $(\mathrm{pH})$, indicator oksigen, dan indicator kebersihan kolam. Indikator gambar ikan akan menampilkan gambar ikan yang ada di dalam kolam, ketika kolam kosong maka indikator gambar ikan juga kosong. Gambar 9. (b) adalah implementasi disain dan rancangan untuk Tugas "Main" yang menampilkan daftar tugas terkait budidaya ikan. Sedangkan Gambar 9 (c) adalah implementasi disain dan rancangan untuk Tugas "Sub" yang menampilkan informasi terkait jumlah pesanan Lele.
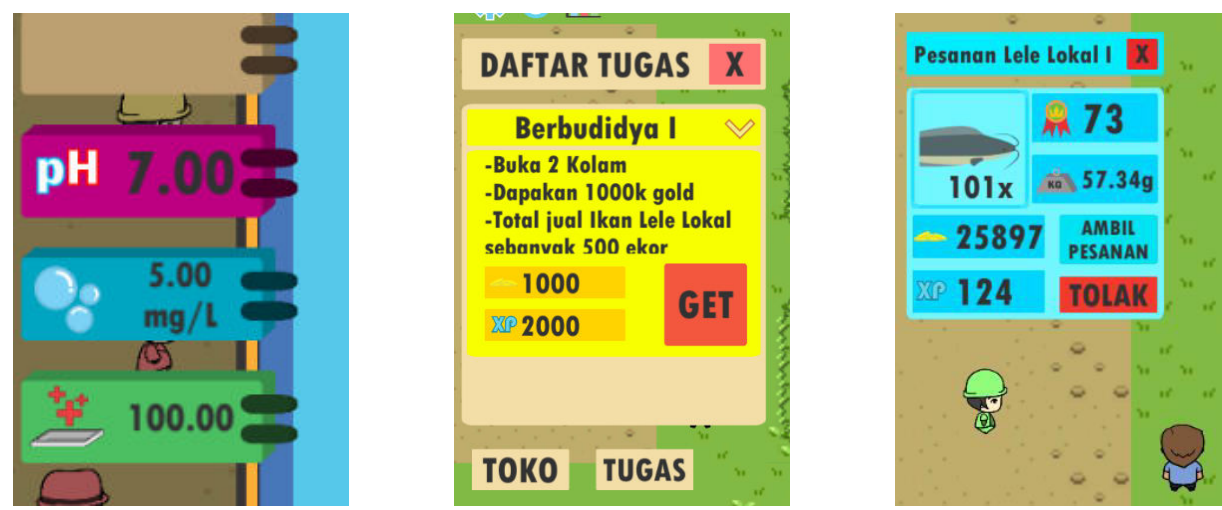
(a)

(b)

(c)

Gambar 9. Implementasi disain dan rancangan (a) Indikator Kolam saat mempersiapkan kolam (b) Tugas "Main" yang menampilkan daftar tugas (c) Tugas "Sub" yang menampilkan informasi terkait jumlah pesanan Lele

Evaluasi dan pengujian pada game dilakukan untuk mengetahui apakah game yang telah dikembangkan dan dibuat dapat berjalan sesuai dengan tujuan yang direncanakan. Penelitian ini tidak menunjukkan proses evaluasi konten dari pakar, karena selama proses desain dan imlementasi didampingi oleh pakar. Ada dua pengujian yang dilakukan yaitu pengujian untuk mengetahui respon pemain menggunakan GameFlow Test [18] dan pengujian angket untuk mengetahui game yang dikembangkan dapat dijadikan sebagai media informasi pembiakan Lele bagi pemain. Ada 30 responden dengan rentang usia 17-25 tahun yang dilibatkan dalam pengujian dan evaluasi. Mereka diminta untuk memainkan game selama kurang lebih 30 menit dan setelah itu mengisi angket yang disediakan.

Penilaian kepuasan responden dalam memainkan game akan dinilai menggunakan Game Flow Test, dengan poin-poin pengujian yang disesuaikan dengan game yang dikembangkan. Responden diminta untuk mengisi jawaban dalam skala Likert dengan rentang nilai 1-5. Nilai 5=POSITIF
(Sangat Setuju) dan 1=NEGATIF (Sangat tidak setuju) untuk setiap poin penilaian.

Hasil Game Flow Test yang dilakukan memberikan rata rata nilai 3,36 . Hal ini menunjukkan bahwa secara umum pemain memberikan respon yang positif. Namun, ada beberapa sub permasalahan yang perlu dikaji ulang, diantaranya pada elemen konsentrasi dan tantangan.

Pada elemen konsentrasi, pemain menyatakan bahwa pemain belum bisa bermain game dalam waktu yang lama. Game Flow Test ternyata belum bisa menunjukkan secara spesifik, mengapa pemain tidak bisa bermain game dalam waktu yang lama.

Elemen Tantangan juga menunjukkan ada sebuah sub pernyataan yang menyatakan bahwa pemain merasa tantangan tidak sesuai dengan tingkat kemampuan pemain. Namun, Game Flow Test ini kurang menjelaskan apakah tantangan ini kurang sulit ataukah terlalu mudah. Selain itu, Game Flow Test belum bisa menjelaskan bagaimana cara pengembang game memperbaiki tingkat kesulitan ini. Keseluruhan hasil pengujian menggunakan Game Flow Test dapat dilihat pada Tabel 1.

Tabel 1. Hasil Pengujian Menggunakan GameFlow Test

\begin{tabular}{|c|c|c|c|c|c|c|c|}
\hline \multirow{2}{*}{ Kategori } & \multirow{2}{*}{ Pernyataan } & \multicolumn{5}{|c|}{ Nilai } & \multirow{2}{*}{$\begin{array}{l}\text { Rata } \\
\text {-rata }\end{array}$} \\
\hline & & 1 & 2 & 3 & 4 & 5 & \\
\hline \multirow{4}{*}{ Konsentrasi } & $\begin{array}{l}\text { Saya bermain game ini dalam } \\
\text { waktu yang lama. }\end{array}$ & 6 & 9 & 11 & 3 & 1 & 2.47 \\
\hline & $\begin{array}{l}\text { Saya tidak terasa terbebani } \\
\text { dengan tantangan/rintangan yang } \\
\text { diberikan pada game? }\end{array}$ & 1 & 7 & 9 & 13 & 0 & 3.13 \\
\hline & $\begin{array}{l}\text { Game yang dikembangkan bisa } \\
\text { dimainkan menyesuaikan } \\
\text { kemampuan yang saya miliki. } \\
\text { Game tidak membebani dengan }\end{array}$ & 0 & 3 & 10 & 14 & 3 & 3.57 \\
\hline & $\begin{array}{l}\text { tugas tambahan yang tidak } \\
\text { penting }\end{array}$ & 0 & 9 & 11 & 9 & 1 & 3.07 \\
\hline
\end{tabular}




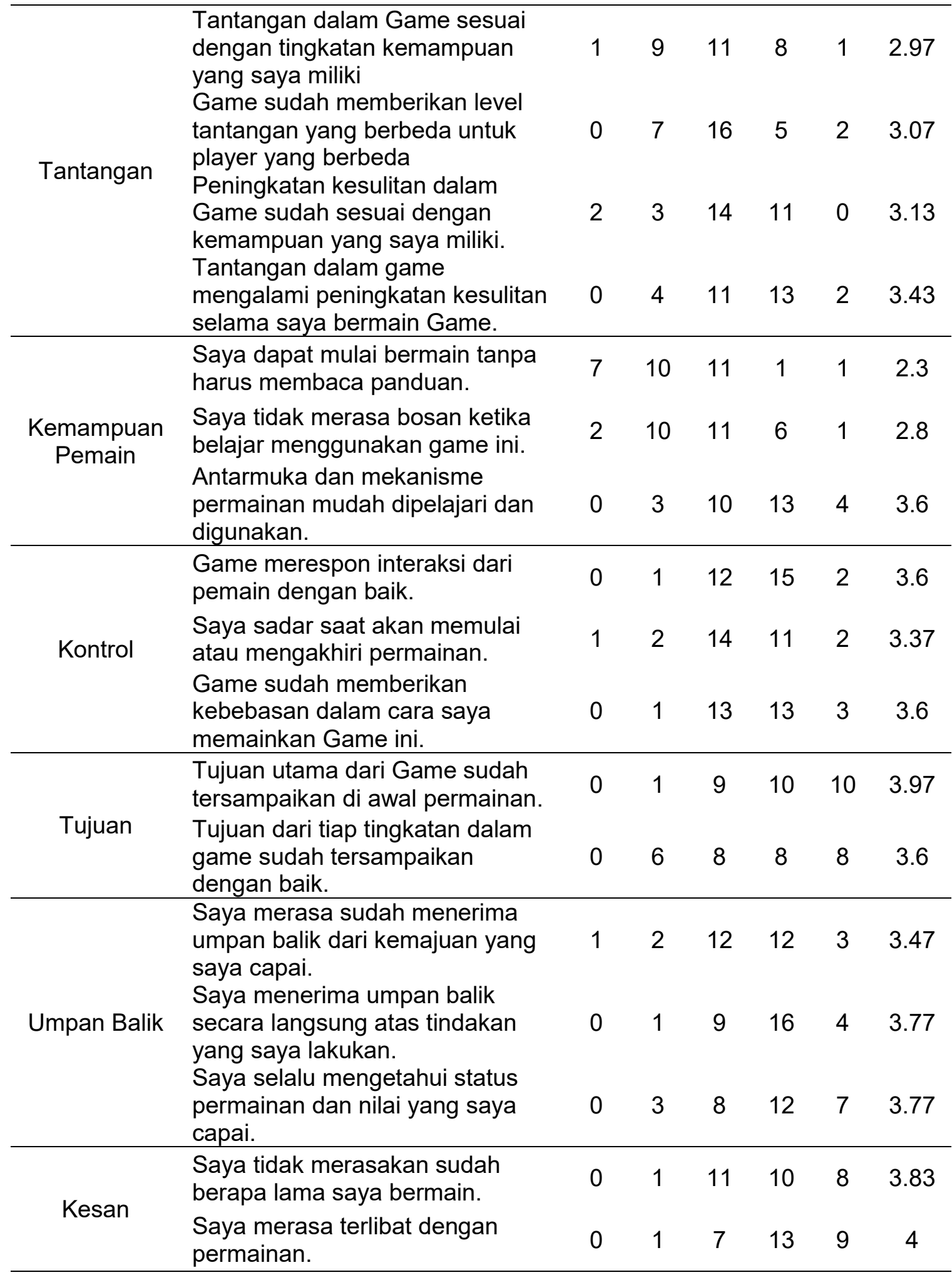

Pada pengujian angket game sebagai media informasi pemain atau responden diberikan beberapa pertanyaan sebelum (pre-test) dan sesudah (post-test) bermain game. Hasil pre-test menunjukan $80 \%$ responden tahu tentang game edukasi dan $66 \%$ pernah memainkan Game edukasi. Sedangkan $40 \%$ responden memiliki pengalaman memainkan game dengan jenis budidaya ikan. Selain itu, $60 \%$ responden menyukai Game sebagai media dalam 
mendapatkan informasi. Hal ini menunjukkan bahwa responden yang diambil memiliki pengetahuan dan pengalaman yang cukup baik dalam kaitannya dengan game edukasi bahkan menjadikan game sebagai sumber informasi.

Hasil post-test menunjukan $80 \%$ menyukai game edukasi dengan jenis budidaya Ikan dan menyatakan bisa membantu dalam proses mempelajari budidaya ikan pada proses pembesaran.
Sedangkan $56 \%$ responden menyatakan game yang dibuat bisa memberikan informasi yang lebih baik dibandingkan dengan media lain. Hasil post-test ini menunjukkan bahwa ada ketertarikan dalam menggunakan game sebagai media pembelajaran, walaupun dalam hal ini informasi pembelajaran budidaya ikan yang diberikan dalam game ini masih dirasa kurang. Hasil keseluruhan pada pengujian angket dapat dilihat pada Tabel 2.

Tabel 2. Hasil Pengujian Game sebagai Media Informasi

\begin{tabular}{lcc}
\hline \multicolumn{1}{c}{ Pertanyaan Sesi 1 (Pre-Test) } & Ya & Tidak \\
\hline Apakah Anda tau apa itu Game Edukasi ? & 24 & 6 \\
\hline Apakah Anda pernah bermain Game Eduaksi ? & 20 & 10
\end{tabular}

Apakah Anda lebih menyukai Game sebagai media dalam mendaptkan informasi secara langsung dibandingkan dengan media lain (buku, 18 12 artikel, atau video) ?

Apakah Anda pernah memainkan Game bertema Budidaya Ikan? 12 18

Pertanyaan Sesi 2 (Post-Test)

Apakah Anda suka dengan Game edukasi seperti ini ?

24 6

Apakah Game edukasi seperti ini membantu anda dalam mempelajari proses pembesaran dalam budidaya ikan ?

Apakah Anda merasa bahwa game mampu memberikan informasi yang lebih baik daripada media buku, artikel di internet, atau video tutorial/informasi ?

Apakah Anda tertarik untuk bermain Game edukasi yang lain untuk beberapa waktu kedepan?

\section{SIMPULAN}

Game edukasi pembiakan Lele yang dibuat menggunakan MDA Framework menunjukan hasil yang baik pada beberapa kriteria yang ditanyakan pada Game Flow Test. Kriteria Game Flow Test yang dianggap baik tersebut di antaranya adalah kriteria kontrol, tujuan, umpan balik dan kesan. Adapun untuk kriteria konsentrasi, tantangan, dan kemampuan pemain masih perlu dikaji ulang. Meskipun ketiga kriteria ini memiliki nilai rata-rata yang baik, ada beberapa sub kriteria yang menunjukkan nilai yang kurang. Hasil pengujian yang ke dua menunjukkan bahwa game yang dikembangkan dapat memberikan informasi yang lebih baik dibandingkan dengan media lain seperti buku dan video.

\section{UCAPAN TERIMAKASIH}

Kami ucapkan terima kasih kepada bapak Riza Rahman Hakim, S.Pi, M.Sc 
dosen Program Studi Akuakultur, Fakultas Pertanian dan Peternakan, Universitas Muhammadiyah Malang atas informasi yang diberikan terkait bagaimana budidaya ikan Lele. Terima kasih kepada Fakultas Teknik Universitas Muhammadiyah Malang untuk program Pengembangan Kerekayasaan dan Teknologi (P2KT) Pusat Kajian Rekayasa dan Teknologi Penelitian (Puskarekatek) atas dukungan secara finansial dalam penerbitan makalah ini.

\section{REFERENSI}

[1] R. E. Ferdig, Handbook of Research on Effective Electronic Gaming in Education Set of 3. 2011.

[2] R. Zheng and M. K. Gardner, Handbook of Research on Serious Games for Educational ApplicationsInformation Science Reference. 2017.

[3] Anonymous, "Potensi usaha budidaya ikan air tawar," Kementrian Kelautan dan Perikanan, 2015. [Online]. Available:

https://news.kkp.go.id/index.php/pote nsi-usaha-budidaya-ikan-air-tawar/. [Accessed: 12-Jul-2019].

[4] Alif Nazzala Rizqi, "Budidaya Ikan Air Tawar Masih Terbuka Lebar," Bisnis Indonesia, 2017. [Online]. Available: https://ekonomi.bisnis.com/read/2017 1112/99/708231/budidaya-ikan-airtawar-masih-terbuka-lebar. [Accessed: 12-Jul-2020].

[5] Y. A. Pradana, "Pelatihan Budidaya Ikan Air Tawar dalam Rangka Meningkatkan Kompetensi dan Produktivitas Masyarakat," Balai Besar Pengembangan Latihan Masyarakat - Kementerian Desa, Pembangunan Daerah Tertinggal, dan Transmigrasi Republik Indonesia, 2017. [Online]. Available: http://bbplm-

jakarta.kemendesa.go.id/view/detil/1 76/pelatihan-budidaya-ikan-air-tawardalam-rangka-meningkatkankompetensi-dan-produktivitasmasyarakat. [Accessed: 12-Jul2020].

[6] F. Y. Al Irsyadi and Y. S. Nugroho,
"Game Edukasi Pengenalan Anggota Tubuh Dan Pengenalan Angka Untuk Anak Berkebutuhan Khusus (ABK) Tunagrahita Berbasis Kinect," Pros. SNATIF, vol. 2, pp. 1-8, 2015.

[7] A. Fairuzabadi and A. A. Supianto, "An Overview Of Learning Support Factors On Mathematic Games," Kinet. Game Technol. Inf. Syst. Comput. Network, Comput. Electron. Control, vol. 4, no. 2, pp. 169-178, 2019, doi: 10.22219/kinetik.v4i2.761.

[8] A. A. Syahidi, H. Tolle, A. A. Supianto, and T. Hirashima, "Educational Media Design for Learning Basic Programming in Branching Control Structure Material Using Problem-Posing Learning Model," Kinet. Game Technol. Inf. Syst. Comput. Network, Comput. Electron. Control, vol. 4, no. 4, pp. 325-336, 2019, doi: 10.22219/kinetik.v4i4.803.

[9] L. Husniah, F. Fannani, A. S. Kholimi, and A. E. Kristanto, "Game Development to Introduce Indonesian Traditional Weapons using MDA Framework," Kinet. Game Technol. Inf. Syst. Comput. Network, Comput. Electron. Control, vol. 4, no. 1, pp. 27-36, 2018, doi: 10.22219/kinetik.v4i1.713.

[10] L. Husniah, B. F. Pratama, and H. Wibowo, "Gamification And GDLC (Game Development Life Cycle) Application For Designing The Sumbawa Folklore Game "The Legend Of Tanjung Menangis (Crying Cape)"," Kinet. Game Technol. Inf. Syst. Comput. Network, Comput. Electron. Control, vol. 3, no. 4, pp. 351-358, 2018, doi: 10.22219/kinetik.v3i4.721.

[11] C. Taurusta, "Rancang Bangun Game Algoritma Dan Struktur Data Berbasis Role Playing Game (Rpg) Sebagai Media Pembelajaran Mahasiswa Teknik Informatika Universitas Muhammadiyah Sidoarjo," Kinetik, vol. 2, no. 3, pp. 175-188, 2017, doi: 10.22219/kinetik.v2i3.167. 
Edukasi Fisika Berbasis Smartphone Android Sebagai Media Pembeajaran Fisika," Indones. J. Sci. Math. Educ., vol. 2, no. 2, pp. 162-167, 2019, doi: 10.24042/ijsme.v2i2.4341.

[13] Anonymous, "ikan - Android Apps on Google Play," 2020. [Online].

Available:

https://play.google.com/store/search? $\mathrm{q}=\mathrm{ikan} \& \mathrm{c}=$ apps\&hl=en. [Accessed: 12-Jul-2020].

[14] P. Republik Indonesia, "Peraturan Pemerintah Republik Indonesia Nomor 28 Tahun 2017 Tentang Pembudidayaan Ikan." Jakarta, 2017.

[15] D. N. S. R. Suyanto, Budidaya Ikan
Lele (ed. Revisis). Niaga Swadaya, 2004.

[16] R. Hunicke, M. Leblanc, and R. Zubek, "MDA: A formal approach to game design and game research," AAAI Work. - Tech. Rep., vol. WS04-04, pp. 1-5, 2004.

[17] M. Gallant, "Mechanics, Dynamics \& Aesthetics," 2009. [Online]. Available: http://gangles.ca/2009/08/21/mda/. [Accessed: 19-Jul-2020].

[18] P. Sweetser and P. Wyeth, "GameFlow," Comput. Entertain., vol. 3, no. 3, pp. 3-3, Jul. 2005, doi: 10.1145/1077246.1077253. 